\title{
SURGICAL TREATMENT OF CYSTIC NEOPLASMS OF THE PANCREAS
}

\author{
Júlio Cezar Uili COELH01,2, Christian Lopez VALLE², Bruno Moraes RIBAS², \\ Leonardo Dudeque ANDRIGUETTO² and Christiano Marlo Paggi CLAUS ${ }^{2}$
}

\begin{abstract}
Context - Diagnosis and treatment of cystic neoplasms of the pancreas increased significantly in the last decades. There are only a few Brazilian publications on these tumors. The majority of them are limited to reports of one or few cases. Objective - To present our experience with 27 patients with cystic neoplasms of the pancreas. Methods - Demographic data, clinical manifestations, diagnostic exams, surgical procedures, postoperative complications, and follow-up data of 27 patients with cystic neoplasms of the pancreas were analyzed, according to the histological type of the tumor. Results - There were $10(37 \%)$ serous cystic tumors, $10(37 \%)$ mucinous cystic tumors, $4(15 \%)$ intraductal papillary mucinous tumors, and $3(11 \%)$ solid pseudopapillary tumors or Frantz tumor. All serous cystic tumors, $6(60 \%)$ mucinous tumors, $2(50 \%)$ intraductal papillary mucinous tumors, and 2(67\%) solid pseudopapillary tumors were benign. The age of the patients varied from 31 to 82 years and all tumors were more common in female. Two patients had been treated previously as a pseudocyst. Surgical procedures depended on the location and extension of the tumor. Two patients underwent only laparotomy with tumor biopsy, one cholecystectomy with Roux-en-Y hepaticojejunostomy for jaundice treatment, 6 pancreatoduodenectomy, and 18 partial pancreatectomy. The most common postoperative complication was pancreatic fistula $(\mathrm{n}=5 ; 19 \%)$. One patient died of necrotic pancreatitis. Of the 10 patients with serous cystic tumor, only 1 had tumor recurrence at the section border. The three patients with mucinous cystoadenocarcinoma in which was not possible to resect the tumor, died 6 to 24 months after laparotomy. The six patients with benign mucinous tumors did not have tumor recurrence. Conclusions - The most common cystic neoplasms of the pancreas are serous and mucinous cysts. These tumors are more frequent in female. Although almost all serous cysts are benign, $40 \%$ of mucinous cysts are malign. Misdiagnosis may delay appropriate treatment and increase mortality.

HEADINGS - Pancreatic neoplasms. Neoplasms, cystic, mucinous, and serous. Pancreatic cyst. Pancreatic fistula. Pancreatitis
\end{abstract}

\section{INTRODUCTION}

With the widespread use of high-quality imaging exams, such as ultrasonography, tomography, and magnetic resonance, an increasing number of patients with cystic neoplasms of the pancreas (CNP) is being identified $^{(6,9)}$. The diagnosis of larger number of patients with CNP allowed a better understand of the natural history these neoplasms ${ }^{(18,35)}$. In addition, other cystic neoplasms, such as intraductal papillary mucinous tumor and solid pseudopapillary tumor were recognized $(15,20,28,30)$.

Although Kloppel and Kosmahl ${ }^{(17)}$ have described 14 types of CNP, the most commonly encountered cystic neoplasms may be classified into four categories: serous cystadenoma, mucinous cystic neoplasms (cystadenoma or cystadenocarcinoma), intraductal papillary mucinous tumor and solid pseudopapillary tumor (Franz tumor). High-quality imaging is essential for the evaluation of patients with $\mathrm{CNP}^{(2)}$. Multi-sliced tomography has become the most common method for assessing pancreatic cysts ${ }^{(2)}$. Magnetic resonance also provides excellent characterization of cyst morphology and may allow diagnosis of peripheral intraductal papillary mucinous tumor. Endoscopic retrograde cholangiopancreatography has a limited role in the evaluation of CNP, but may be useful in the diagnosis of intraductal papillary mucinous tumor. Endoscopic ultrasound has become a valuable tool in the assessment of $\mathrm{CNP}^{(12)}$. Fluid may be obtained by fine-needle aspiration and may be used for cytologic and tumor markers analysis. Elevated CEA levels (>192 $\mathrm{ng} / \mathrm{mL}$ ) in the fluid aspirated is the best predictor of a mucinous lesion ${ }^{(4)}$.

Due to the increase in the diagnosis of CNP, the number of pancreatectomies for treatment of these tumors expanded significantly ${ }^{(1,16)}$. Although CNP account for less than $10 \%$ of all pancreatic neoplasms, up to $30 \%$ of pancreatic resections are performed to treat these neoplasms ${ }^{(8)}$. The rate of pancreatectomies used to treat CNP at the Massachusetts General Hospital in Boston, USA, increased from $16 \%$ to $30 \%$ in the last decade $^{(8)}$. There are only a few Brazilian publications on $\mathrm{CNP}$ and the majority of them are limited to report of one or few cases $^{(5,6,23,25,26)}$. Our objective is to present our experience in the surgical treatment of CNP.

Division of Gastrointestinal Surgery, Hospital de Clinicas, Federal University of Paraná; ${ }^{2}$ Hospital Nossa Senhora das Graças, Curitiba, PR, Brazil. Correspondence: Prof. Júlio Coelho - Rua Bento Viana, 1140 - apt. 2202 - 80240-110 - Curitiba, PR, Brazil 


\section{METHODS}

A total of 27 patients with CNP who were subjected to surgical treatment at the Division of Gastrointestinal Surgery of the Federal University of Paraná and Hospital Nossa Senhora das Graças of Curitiba, PR, Brazil, from January 1998 to July 2008 was studied. Demographic data, clinical manifestations, diagnostic tests, surgical procedures, and postoperative complications and course were evaluated, depending on the histological type of CNP. The diagnosis of CNP was confirmed by histological exam in all patients.

Seven patients with CNP who were not subjected to surgical treatment during this period due to advanced age, surgical treatment refusal or preference for clinical follow-up were excluded from the study. Approval from the Hospital Ethical Committee was obtained for conducting the study.

\section{RESULTS}

Histological exam diagnosed 10 (37\%) serous tumors, 10 $(37 \%)$ mucinous tumors, $4(15 \%)$ intraductal papillary mucinous neoplasms, and $3(11 \%)$ solid pseudopapillary neoplasms or Frantz tumors. All cystic serous tumors, 6 (60\%) mucinous tumors, $2(50 \%)$ intraductal papillary mucinous tumors, and $2(67 \%)$ solid pseudopapillary tumors were benign.

\section{Demographic data and clinical manifestations}

Table 1 shows the age, sex and clinical manifestations of the patients with CNP, according to histological type of the tumor. The age of all patients varied from 33 to 72 years for serous tumors, 31 to 82 for mucinous tumors, 45 to 81 for intraductal papillary mucinous tumor, and 30 to 52 for solid pseudopapillary tumor. All CNP were more common in female and all mucinous cystic tumors were observed in women.

Clinical manifestations were similar in all types of CNP. Abdominal pain and sensation of abdominal weight were the most common symptoms. Jaundice occurred in patients with CNP of the pancreatic head. Weight loss was observed in two patients with mucinous tumor and two with intraductal papillary mucinous tumor.

One patient who complained of persistent upper abdominal pain had been subjected to percutaneous drainage of a pseudocyst 6 months earlier in other hospital.
Lower digestive hemorrhage (enterorrhagia and melena) was the main clinical manifestation of a patient who had undergone a cystojejunostomy in Roux-en-Y 6 months earlier in other hospital for treatment of pancreatic "pseudocyst". An abdominal tomography showed a persistent $10 \mathrm{~cm}$ cyst of the tail of the pancreas. At laparotomy, it was found a mucinous cystic tumor anastomosed to a Roux-en-Y jejunal segment. The mesocolon near to the anastomosis was infiltrated by tumor. The patient was subjected to tail pancreatectomy with splenectomy. The histological examination revealed a mucinous cystadenocarcinoma of the pancreas.

\section{Tumor location and size}

All patients were subjected to 2 or 3 of the following imaging exams: ultrasonography, tomography, and magnetic resonance (Figure 1). Ecoendoscopy was performed in three patients and endoscopic retrograde cholangiopancreatography in two. Preoperative diagnosis of all patients was CNP. However, the ultrasonographic diagnosis was pancreatic pseudocyst in three patients with serous tumor and in two with mucinous tumor. The tomographic and magnetic resonance report suggested the diagnosis of CNP in all five patients. The size and location of the tumors, according to the type of neoplasm are shown in Table 2. The size of CNP varied from 5 to $12 \mathrm{~cm}$

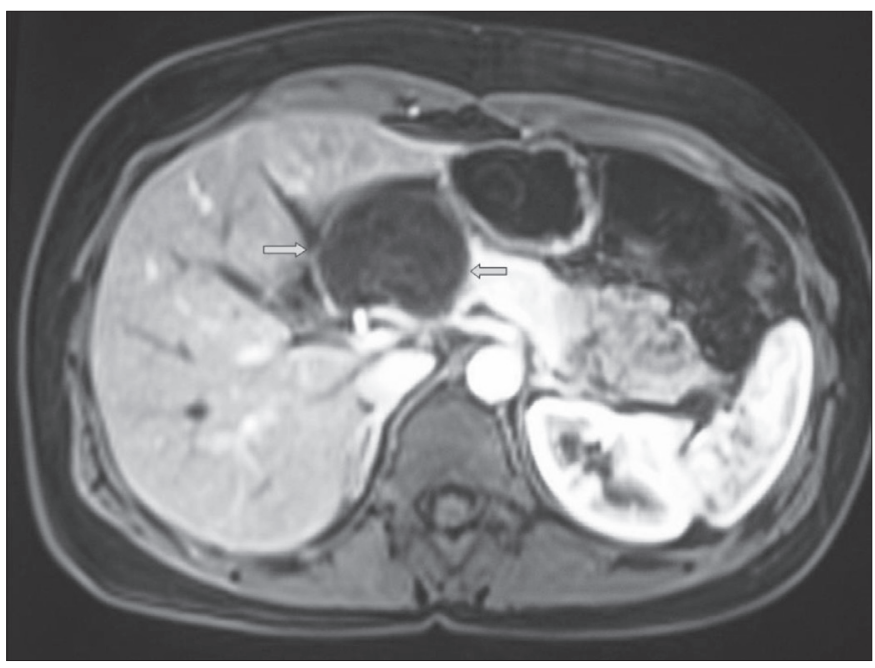

FIGURE 1. Magnetic resonance showing a mucinous cystadenoma in the pancreatic head (arrows)

TABLE 1. Demographic data and clinical manifestations of the patients, according to the type of cystic neoplasm of the pancreas ( $\mathrm{n}=27$ )

\begin{tabular}{|c|c|c|c|c|}
\hline & $\begin{array}{l}\text { Serous cystic tumor } \\
\qquad(\mathrm{n}=10)\end{array}$ & $\begin{array}{l}\text { Mucinous cystic tumor } \\
\qquad(\mathrm{n}=10)\end{array}$ & $\begin{array}{l}\text { Intraductal papillary mucinous tumor } \\
\qquad(\mathrm{n}=4)\end{array}$ & $\begin{array}{l}\text { Solid pseudo-papillary tumor } \\
\qquad(\mathrm{n}=3)\end{array}$ \\
\hline Age mean $\pm \mathrm{SD}$ (years) & $51 \pm 12$ & $53 \pm 10$ & $62 \pm 19$ & $40 \pm 9$ \\
\hline Age, range (years) & 33 to 72 & 31 to 82 & 45 to 81 & 30 to 52 \\
\hline Female, n $(\%)$ & $7(70 \%)$ & $10(100 \%)$ & $3(75 \%)$ & $2(67 \%)$ \\
\hline \multicolumn{5}{|l|}{ Clinical manifestation, $\mathrm{n}(\%)$} \\
\hline -Abdominal pain & $9(90 \%)$ & $9(90 \%)$ & $4(100 \%)$ & $2(67 \%)$ \\
\hline -Abdominal weight & $6(60 \%)$ & $7(70 \%)$ & $4(100 \%)$ & $2(67 \%)$ \\
\hline -Weight loss & 0 & $2(20 \%)$ & $2(50 \%)$ & 0 \\
\hline -Jaundice & $1(10 \%)$ & $2(20 \%)$ & $2(50 \%)$ & $1(33 \%)$ \\
\hline -Digestive hemorrhage & 0 & $1(10 \%)$ & 0 & 0 \\
\hline -Asymptomatic & $1(10 \%)$ & 0 & 0 & $1(33 \%)$ \\
\hline
\end{tabular}

$\mathrm{SD}=$ standard deviation 
TABLE 2. Tumor size and location, according to the type of cystic neoplasm of the pancreas $(n=27)$

\begin{tabular}{|c|c|c|c|c|}
\hline & $\begin{array}{l}\text { Serous cytic tumor } \\
\quad(\mathrm{n}=10)\end{array}$ & $\begin{array}{l}\text { Mucinous cystic tumor } \\
\qquad(\mathrm{n}=10)\end{array}$ & $\begin{array}{l}\text { Intraductal papillary mucinous tumor } \\
\qquad(\mathrm{n}=4)\end{array}$ & $\begin{array}{l}\text { Solid pseudo-papillary tumor } \\
\qquad(\mathrm{n}=3)\end{array}$ \\
\hline Size mean $\pm \mathrm{SD}(\mathrm{cm})$ & $7,2 \pm 2,3$ & $8,3 \pm 2,1$ & $4,5 \pm 1,7$ & $7,3 \pm 1,9$ \\
\hline Size, range $(\mathrm{cm})$ & 5 to 12 & 4,4 to 12 & 3 to 7 & 5 to 9 \\
\hline \multicolumn{5}{|l|}{ Location, n (\%) } \\
\hline - head/ uncinate process & $2(20 \%)$ & $3(30 \%)$ & $2(50 \%)$ & $2(67 \%)$ \\
\hline - body & $7(70 \%)$ & $4(40 \%)$ & $2(50 \%)$ & $1(33 \%)$ \\
\hline - tail & $1(10 \%)$ & $3(30 \%)$ & 0 & 0 \\
\hline
\end{tabular}

$\mathrm{SD}=$ standard deviation

for serous tumors, 4.4 to $12 \mathrm{~cm}$ for mucinous tumors, 3 to 7 $\mathrm{cm}$ for intraductal papillary mucinous tumors and 5 to $9 \mathrm{~cm}$ for solid pseudopapillary tumors. The majority of serous and mucinous tumors were located in the body of the pancreas, half of the intraductal papillary mucinous tumors in the head and $2 / 3$ of the solid pseudopapillary tumors in the head.

\section{Surgical procedures and postoperative complications}

The operations performed depended on the location and extension of the tumor. Two patients with mucinous tumor of the pancreatic head underwent only laparotomy with biopsy of the tumor or metastasis. Pancreatoduodenectomy was not performed due to the presence of metastasis (one patient) or advanced age ( 82 years). One other patient with mucinous tumor of the head of the pancreas and the presence of metastasis underwent only cholecystectomy and Rouxen-Y hepaticojejunostomy to treat the jaundice. The other six patients with pancreatic tumor of the head and or uncinate process were subjected to pancreatoduodenectomy with (four patients) or without (two patients) pylorus preservation.

All patients with tumor of pancreatic body $(n=14)$ underwent pancreatectomy of the body and tail with splenectomy. Four patients with tumor of the pancreatic tail underwent either distal pancreatectomy with splenectomy $(n=3)$ or distal pancreatectomy with spleen preservation $(n=1)$.

The most common postoperative complication was pancreatic fistula, which occurred in five patients $(18.5 \%)$. All fistulas closed with conservative treatment. Postoperative complications are shown in Table 3. One patient who presented with stenosis of the gastroenteroanastomosis after pancreatoduodenectomy was subjected to surgical revision of the anastomosis. One patient who underwent pancreatoduodenectomy due to solid pseudopapillary tumor developed diabetes mellitus 1 year after the operation. Both

TABLE 3. Postoperative complications $(\mathrm{n}=27) *$

\begin{tabular}{lll}
\hline Complications & $\mathbf{n}$ & $\%$ \\
\hline Pancreatic fistula & 5 & 19 \\
Wound infection & 3 & 11 \\
Incisional hernia & 3 & 11 \\
Pneumonia & 1 & 4 \\
Gastroenteroanastomosis stricture & 1 & 4 \\
Diabetes mellitus & 1 & 4 \\
Necrotizing acute pancreatitis & 1 & 4 \\
Death & 1 & 4 \\
\hline
\end{tabular}

* Some patients had more than one complication of his parents had diabetes mellitus type II. The patient with cystoadenocarcinoma who had undergone Roux-en-Y cystojejunostomy in other hospital was subjected to distal pancreatectomy with splenectomy. This patient died on the 22 nd postoperative day due to necrotizing acute pancreatitis.

\section{Follow-up}

Follow-up ranged from 6 months to 12 years (mean of $3 \pm$ 2.2 years). Of the 10 patients with serous cystoadenoma, only 1 had tumor recurrence near the section line of the pancreas 4 years after the operation. This patient was not subjected to other operation due to the small size of the tumor $(3 \mathrm{~cm})$ and also because the patient was asymptomatic and the benign nature of the lesion has already been established.

The three patients with mucinous cystadenocarcinoma who were not subjected to tumor resection died 6 to 24 months after the operation. The patient with mucinous cystadenocarcinoma who was unduly treated as pseudocyst died 8 months after the pancreatectomy. There was no tumor recurrence in the six patients with benign mucinous neoplasms.

One patient with malignant intraductal papillary mucinous tumor had recurrence of the lesion 2 years after the resection. There was no tumor recurrence in the other patients with this type of tumor and in the three patients with solid pseudopapillary tumor.

\section{DISCUSSION}

CNP comprises a heterogeneous group of benign, premalignant, and malignant tumors. The most commonly encountered cystic neoplasms are serous cyst (serous cystadenoma), mucinous cyst (mucinous cystadenoma and mucinous cystadenocarcinoma), intraductal papillary mucinous tumor, and solid pseudopapillary tumor $(2,22,27,34)$. More than 2/3 of the CNP are either serous or mucinous cystic tumors $^{(1,2,3)}$. The majority of CNP occur in female, except the intraductal papillary mucinous tumor, which has a similar incidence in both $\operatorname{sexes}^{(2,21,24,35)}$.

Almost all serous cystic tumors are benign. Only fewer than 10 cases of malignant serous cyst tumors have been reported in the worldwide literature $(2,3,10,11,14)$. About $10 \%$ to $50 \%$ of the mucinous cystic tumors of the pancreas are malignant $t^{2}$, ${ }^{13,35)}$. The malignancy incidence in the intraductal papillary mucinous tumor and in the solid pseudopapillary tumor ranges from $50 \%$ to $90 \%$ and $10 \%$ to $20 \%$, respectively ${ }^{(2,15}$, 24, 29,33). The incidence of malignancy in the CNP observed 
in our study was similar to that of the literature. All serous tumors, $60 \%$ of the mucinous tumors, and $50 \%$ of the intraductal papillary mucinous tumors were benign. However, the incidence of malignancy in solid pseudopapillary tumor was higher in our series, possibly due to the reduced number of these tumors in our experience.

The size of CNP varies widely from lesions of few millimeters to tumors larger than $20 \mathrm{~cm}$, which involve the entire pancreas ${ }^{(10,32)}$. In our experience, almost all tumors were larger than 4 to $5 \mathrm{~cm}$, because in the present series it was included only patients with tumors that were treated surgically. Patients with CNP that are treated surgically have neoplasms larger than those who are treated conservatively, without surgical procedure ${ }^{(10,19,32)}$.

Clinical manifestations depend on the size and location of the tumor. Abdominal pain and sensation of abdominal weight or epigastric fullness were the most common symptoms observed in our series. Jaundice due to biliary obstruction was observed in patients with tumors of the pancreatic head. Digestive hemorrhage and weight loss are less frequent symptoms. Many patients with CNP present with no relevant clinical manifestations ${ }^{(4)}$.

Although CNP may be usually distinguished from pseudocyst of the pancreas based on clinical aspects and imaging exams features, two of our patients and others of Brazilian literature were unduly treated as pseudocyst in other hospital $^{(21)}$. Erroneous diagnosis delays adequate treatment and increases the possibility of tumor dissemination, as observed in one of our patients who underwent an unduly Roux-en-Y cystojejunostomy in other hospital.

With improvement of our knowledge of the biological behavior of CNP in the last decades, the treatment of these lesions has changed ${ }^{(3)}$. The management of these neoplasms depend on several factors, including their size, presence of clinical manifestations, location of the tumor, age and medical condition of the patient, and identification the premalignant or malignant features ${ }^{(3,11,14)}$. Tumor resection is indicated in patients with potentially malignant or malignant lesions and in patients who have clinical manifestations, independent on the biological behavior of the tumor. In general, all patients with cystic tumor of the pancreas should undergo pancreatic resection, except those with either asymptomatic serous cystadenoma or intraductal papillary mucinous neoplasm smaller than $2-3 \mathrm{~cm}$. However, serial clinical and radiographic follow-up is recommended. Changes in character, growth of the lesion, or development of symptoms indicate need for pancreatic resection $^{(27)}$.

When diagnostic evaluation identifies a serous cystadenoma, resection should be reserved for the symptomatic patient and for the healthy patient in whom significant growth has been observed $^{(2)}$. In general, all patients with either mucinous cystic neoplasm or solid pseudopapillary tumor should undergo pancreatic resection $^{(27)}$. About $50 \%$ of these patients will harbor carcinoma at operation ${ }^{(2)}$.

Surgical treatment depends on the location, and extension of the tumor. Distal pancreatectomy, with spleen preservation, whenever possible, should be performed for CNP located in the body and tail of the pancreas. Small lesions of the neck of the pancreas may be treated with segmental middle pancreatectomy, with stapler closing of the proximal pancreatic segment and drainage of the distal segment with a Roux-en-Y pancreatojejunostomy. Tumors of the head and or uncinate process should be treated with pancreatoduodenectomy, with or without pylorus preservation.

It is important to remove the entire cystic tumor, with special care not to rupture the lesion. Spillage of gelatinous content of the neoplasm may cause tumor implantation and dissemination into the abdominal cavity, causing pseudomixoma peritoneal. Tumor enucleation should not be performed due to the elevated risk of complications, mainly pancreatic fistula. In addition, tumor recurrence may occur at the pancreatic surgical margin.

Although morbidity and mortality may be low in some centers, pancreatic resections, mainly pancreatoduodenectomies, are associated with several complications. The complication rate varies from $30 \%$ to $40 \%$ in most series ${ }^{(27)}$. In our experience, pancreatic fistula, wound infection, and incisional hernia were the most common complications. The mortality rate of our series $(4 \%)$ was similar to those reported in the literature $(2 \% \text { a } 5 \%)^{(27)}$.

Prognosis of patients with either benign or malignant CNP with no transmural tumor invasion who are subjected to resection is excellent, with cure rate of almost $100 \% \%^{(2,31}$, ${ }^{35)}$. Malignant solid pseudopapillary tumor is local-regionally invasive, but rarely metastatic. The prognosis is excellent, with a cure rate of almost $100 \%$ for lesions with no metastasis ${ }^{(15}$, 30). The survival is long, even for patients with metastasis ${ }^{(15}$, 30). However, 5-year survival rate is of only $30 \%$ to $50 \%$ for patients with invasive mucinous cystadenocarcinoma or intraductal papillary mucinous tumor ${ }^{(7,8,24,29)}$. In our series, three patients with mucinous cystadenocarcinoma who were not subjected to tumor resection died in 6 to 24 months, demonstrating the bad prognosis of these tumors when adequate treatment is not performed.

\section{CONCLUSIONS}

The present study have shown that the most common cystic neoplasms of the pancreas are serous tumors (serous cystadenoma) and the mucinous tumors (mucinous cystadenoma and mucinous cystadenocarcinoma). These tumors are more common in females. Although almost all serous tumors are benign, a significant percentage $(40 \%)$ of mucinous tumors is malignant. Misdiagnosis of these tumors may delay appropriate treatment and increase mortality. 
Coelho JCU, Valle CL. Ribas BM, Andriguetto LD, Claus CMP. Tratamento cirúrgico das neoplasias císticas do pâncreas. Arq Gastroenterol. 2010;47(2):135-40.

RESUMO - Racional - O diagnóstico e tratamento das neoplasias císticas do pâncreas aumentaram significativamente nas últimas décadas. Existem poucas publicações brasileiras sobre estes tumores, sendo que a maioria é limitada à descrição de um ou poucos casos. Objetivo - Apresentar a experiência com 27 pacientes com neoplasia cística do pâncreas. Métodos - Os dados demográficos, quadro clínico, exames complementares, procedimento cirúrgico com as suas complicações e a evolução pós-operatória de 27 pacientes com neoplasia cística do pâncreas foram analisados, conforme o tipo histológico do tumor. Resultados - O exame anatomopatológico evidenciou 10 (37\%) casos de tumor seroso, 10 (37\%) de tumor mucinoso, 4 (15\%) de neoplasia intraductal papilar mucinosa e $3(11 \%)$ de neoplasia sólida pseudopapilar ou tumor de Frantz. Todos os tumores serosos, seis (60\%) mucinosos, dois (50\%) tumores intraductais papilares mucinosos e dois $(67 \%)$ tumores sólidos pseudopapilares eram benignos. A idade dos pacientes variou amplamente de 31 a 82 anos e o sexo feminino predominou em todos os tipos de tumores. Dois pacientes tinham sido tratados previamente como pseudocisto de pâncreas. As operações realizadas dependiam da localização e extensão do tumor. Dois pacientes foram submetidos somente a laparotomia com biopsia do tumor, 1 a colecistectomia e hepaticojejunostomia em Y-de-Roux para aliviar a icterícia, sem ressecção da neoplasia, 6 a pancreatoduodenectomia e 18 a pancreatectomia parcial. A complicação pós-operatória mais comum foi fístula pancreática $(\mathrm{n}=5 ; 19 \%)$. Um paciente morreu no pós-operatório imediato por pancreatite necrótica. Dos 10 pacientes com cistoadenoma seroso, apenas 1 apresentou recidiva próxima à borda de secção do tumor. Os três pacientes com cistoadenocarcinomas mucinosos em que não foi realizada a ressecção do tumor foram a óbito de 6 a 24 meses após a operação. Os seis pacientes com tumores mucinosos benignos não apresentaram recidiva. Conclusães - As neoplasias císticas pancreáticas mais comuns são os cistos serosos e os mucinosos. Estes tumores ocorrem predominantemente no sexo feminino. Apesar de quase todos os tumores serosos serem benignos, uma percentagem elevada (40\%) de tumores mucinosos é maligna. O não reconhecimento desses tumores pode retardar o tratamento adequado e ser associado à elevada mortalidade.

DESCRITORES - Neoplasias pancreáticas. Neoplasias císticas, mucinosas e serosas. Cisto pancreático. Fístula pancreática. Pancreatite.

\section{REFERENCES}

1. Adsay NV. Cystic lesions of the pancreas. Mod Pathol. 2007;20:s71-s93.

2. Allen PJ, Brennam MF. The management of cystic lesions of the pancreas. Adv Surg. 2007;11:211-28.

3. Bassi C, Salvia R, Molinari E, Biasutti C, Falconi M, Pederzoli P. Management of 100 consecutive cases of pancreatic serous cystadenoma: wait for symptoms and see at imaging or vice-versa? World J Surg. 2003;27:319-23.

4. Brugge WR, Lauwers GY, Sahani D, Fernandez-del Castillo C, Warshaw AL. Cystic neoplasms of the pancreas. N Engl J Med. 2004;351:1218-26.

5. Caparossi C, Aguilar-Nascimento JE, Faria MS. Neoplasia papilar cística do pâncreas - tumor de Frantz. Relato de caso. GED Gastroenterol Endosc Dig. 2005,24:144-6.

6. Costa-Neto, GD, Amico EC, Costa GID. Solid-pseudopapillary tumor of the pancreas: report of four cases. Arq Gastroenterol. 2004,41:259-62.

7. D’Angelica M, Brennan MF, Suriawinata AA,Klimstra D, Conlon KC. Intraductal papillary mucinous neoplasms of the pancreas: an analysis of clinicopathologic features and outcome. Ann Surg. 2004;239:400-8.

8. Federle MP, McGrath KM. Cystic neoplasms of the pancreas. Gastroenterol Clin North Am. 2007;36:365-76.

9. Fitzgerald TL, Hickner ZJ, Schmitz M, Kort EJ. Changing incidence of pancreatic neoplasms: a 16-year review of statewide tumor registry. Pancreas. 2008;37:134-8.

10. Friebe V, Keck T, Mattern D, Schmitt-Graeff A, Werner M, Mikami Y, Adam U, Hopt UT. Serous cystadenocarcinoma of the pancreas: management of a rare entity. Pancreas. 2005;31:182-7.

11. Galanis C, Zamani A, Cameron JL, Campbell KA, Lillemoe KD, Caparrelli D, Chang D, Hruban RH, Yeo CJ. Resected serous cystic neoplasms of the pancreas: a review of 158 patients with recommendations for treatment. J Gastrointest Surg. 2007;11:820-6.

12. Guaraldi S, Sá E, Romano S, Carvalho ACP. O papel da ecoendoscopia no diagnóstico das neoplasias císticas primárias do pâncreas. Radiol Bras. 2005;38: $451-8$.

13. Hara T, Kawashima H, Ishigooka M, Kashiyama M, Takanashi S, Yamazaki S, Hosokawa Y. Mucinous cystic tumors of the pancreas. Surg Today. 2002;32:965-9.

14. Hashimoto M, Watanabe G, Matsuda M, Mori M. Serous cystic neoplasm of the pancreas-indications for surgery. Hepatogastroenterology. 2006;53:950-2

15. Kamat RN, Naik LD, Joshi RM, Amrapurkar AD, Shetty TS. Solid pseudopapillary tumor of the pancreas. Indian J Pathol Microbiol. 2008;51:271-3.

16. Katz MH, Mortenson MM, Wang H, Hwang R, Tamm EP, Staerkel G, Lee JH, Evans DB, Fleming JB. Diagnosis and management of cystic neoplasms of the pancreas: an evidence-based approach. J Am Coll Surg. 2007;207:106-20.

17. Kloppel G, Kosmahl M. Cystic lesions and neoplasms of the pancreas. The features are becoming clearer. Pancreatology. 2001;1:648-55.

18. Kubrusly MS, Matheucci Jr, EL, Kátia RM, Coelho AMM, Monte O, Machado MCC, Pinotti HW. Detection of codon 12 mutation in the k-ras oncogene in pancreatic tumors. Rev Hosp Clin Fac Med São Paulo. 1999;54:17-20.

19. Machado MAC, Canedo LF, Herman P, Montagnini AL, Sallum RAA, Machado MCC. Pancreatectomia distal videolaparoscópica em pacientes com cistadenoma de pâncreas. Arq Gastroenterol. 2005;42:157-60.

20. Machado MCC, Cunha JEM, Bacchella T, Jukemura J, Penteado S, Zerbini MCN, Dias TRP, Vianna MR, Pinotti HW. Tumor de Frantz (neoplasia epitelial papilar e cística do pâncreas): estudo de três casos. Rev Hosp Clin Fac Med Univ São Paulo. 1993,48:29-34.

21. Machado MCC, Montagnini AL, Machado MAC, Falzoni T, Volpe P, Jukemura J, Abdo EE, Penteado S, Bacchella T, Cunha JEM, Pinotti HW. Neoplasia cistica do pancreas: analise de 24 casos. Rev Hosp Clin Fac Med Univ São Paulo. 1994,49:208-12.

22. Mortenson MM, Katz MH, Tamm EP, Bhutani MS, Wang H, Evans DB, Fleming JB. Current diagnosis and management of unusual pancreatic tumors. Am J Surg. 2008;196:100-13.

23. Moulim JL, Avelino RP, Batista PA, Llanos JC, Macedo VT, Spadella CT, Minossi JG. Tumor de Frantz (neoplasia epitelial papilar e cística do pâncreas): relato de caso e revisão da literatura. ABCD Arq Bras Cir Dig. 2006,19:26-9.

24. Paye F, Sauvanet A, Terris B. Intraductal papillary mucinous tumors of the pancreas: pancreatic resections guided by preoperative morphological assessment and intraoperative frozen section examination. Surgery. 2000;127:536-44.

25. Reis LDO, Campos GMR, Coelho JCU, Reis ADO, Moraes AG, Pisani JC. Neoplasia papilífera cística do pâncreas. Relato de caso. Rev Med Paraná, 1991,48:43-5.

26. Silva RA, Aguida ST, Coimbra RSM, Pacheco Jr AM, Gonçalves AJ, Rasslan S, Fava J. Cistoadenoma de pâncreas: apresentação de dois casos. Arq Méd Hosp Fac Ciênc Méd Santa Casa São Paulo. 1987;7:50-2.

27. Society for Surgery of the Alimentary Tract. SSAT patient care guidelines. Cystic neoplasms of the pancreas. J Gastrointest Surg. 2007;11:1225-7.

28. Sohn TA, Yeo CJ, Cameron JL. Intraductal papillary mucinous neoplasms of the pancreas: an updated experience. Ann Sug. 2004;239:788-97.

29. Sugiyama M, Suziki Y, Abe N, Mori T, Atomi Y. Management of intraductal papillary mucinous neoplasm of the pancreas. J Gastroenterol. 2008;43:181-5.

30. Tang LH, Aydin H, Brennan MF, Klinstra DS. Clinically aggressive solid pseudopapillary tumor of pancreas: a report of cases with components of undifferentiated carcinoma and a comparative clinicopathologic analysis of 34 conventional cases. Am J Surg Pathol. 2005;29:51-2.

31. Tien YW, Hu RH, Hung JS, Wang HP, Lee PH. Noninvasive pancreatic cystic neoplasms can be safely and effectively treated by limited pancreatectomy. Ann Surg Oncol. 2008;15:193-8. 
32. Tseng JF, Warshaw AL, Sahani DV. Serous cystadenoma of the pancreas: tumor growth rates and recommendations for treatment. Ann Surg. 2005;242:413-9.

33. White R, D'Angelica M, Tang L. The fate of the remnant pancreas following resection of non-invasive intraductal papillary mucinous neoplasm. J Am Coll Surg. 2006;204:987-93.

34. Yoon WJ, Lee JK, Lee KH, Ryu JK, Kim YT, Yoon YB. Cystic neoplasms of the exocrine pancreas: an update of a nationwide survey in Korea. Pancreas. 2008;37:254-8.
35. Zamboni G, Scarpa A, Bogina G, Iacono C, Bassi C, Talamini G, Sessa F, Capella C, Solcia E, Rickaert F, Mariuzzi GM, Klöppel G. Mucinous cystic tumors of the pancreas: clinicopathological features, prognosis, and relationship to other mucinous cystic tumors. Am J Surg Pathol. 1999;23:410-22.

Received:13/4/2009. Accepted:20/8/2009. 